GRASAS Y ACEITES 70 (1)

January-March 2019, e284

ISSN-L: 0017-3495

https://doi.org/10.3989/gya.0215181

\title{
Cucumis melo L. seeds as a promising source of oil naturally rich in biologically active substances: compositional characteristics, phenolic compounds and thermal properties
}

\author{
S. Mallek-Ayadi ${ }^{\bowtie}$, N. Bahloul and N. Kechaou \\ Research Group of Agri-Food Processing Engineering, Laboratory of Applied Fluids Mechanics, Process Engineering \\ and Environment, National School of Engineers of Sfax, University of Sfax, Tunisia. \\ Corresponding author: sana.mallek@yahoo.fr
}

Submitted: 01 February 2018; Accepted: 29 June 2018

\begin{abstract}
SUMMARY: This study aimed to evaluate the characteristic features, phenolic compounds and thermal analysis of melon seed oil (Maazoun variety), in order to determine its potential applications in food or pharmaceutical industries. The physicochemical properties of the seed oil revealed a high degree of unsaturation. The average contents of carotenoid and chlorophyll were $2.43 \mathrm{mg} / \mathrm{kg}$ and $5.70 \mathrm{mg} / \mathrm{kg}$, respectively. The main fatty acids of melon seed oil were linoleic acid (68.98\%) and oleic acid (15.84\%), which makes this oil nutritionally valuable. Furthermore, trilinolein (LLL), accounted for $28.99 \%$ and constitutes the most abundant triacylglycerol. A chromatographic analysis showed that amentoflavone and luteolin-7-glycoside were the major phenolic compounds. A thermal analysis of melon seed oil was performed by differential scanning calorimetery (DSC). The results of sensorial properties indicated that melon seed oil is appreciated by tasters. The findings suggested that because of its composition, melon seed oil could be used successfully as an alternative source in the food and nutraceutical industries as a functional ingredient.
\end{abstract}

KEYWORDS: Fatty acid composition; Melon (Cucumis melo L.); Phenolic compounds; Phytosterols; Seed oil; Sensory analysis; Thermal profile

RESUMEN: Semillas de Cucumis melo L. como prometedora fuente natural de aceite rico en sustancias biológicamente activas: composición, compuestos fenólicos y propiedades térmicas. El objetivo de este estudio fue la caracterización, evaluación de compuestos fenólicos y el análisis térmico del aceite de semillas de melón (variedad Maazoun), con el fin de conocer sus potenciales aplicaciones en la industria alimentaria o farmacéutica. Las propiedades fisicoquímicas del aceite de semilla mostraron un alto grado de insaturación. El contenido promedio de carotenoides y clorofila fue de $2,43 \mathrm{mg} / \mathrm{kg}$ y $5,70 \mathrm{mg} / \mathrm{kg}$, respectivamente. Los principales ácidos grasos del aceite de semilla de melón fueron el linoleico $(68,98 \%)$ y oleico $(15,84 \%)$, lo que hace que este aceite sea nutricionalmente valioso. Además, la trilinoleína (LLL) que representó el 28,99\% constituye el triacilglicerol más abundante. El análisis cromatográfico mostró que amentoflavona y luteolin-7-glucósido eran los principales compuestos fenólicos. El análisis térmico del aceite de semilla de melón se realizó mediante calorimetría diferencial de barrido (DSC). Los resultados de las propiedades sensoriales indicaron que los catadores aprecian el aceite de semilla de melón. Los hallazgos sugieren que, debido a su composición, el aceite de semilla de melón podría utilizarse con éxito como una fuente alternativa en la industria alimentaria y nutracéutica como ingrediente funcional.

PALABRAS CLAVE: Aceite de semilla; Análisis sensorial; Composición de ácidos grasos; Compuestos fenólicos; Fitoesteroles; Melón (Cucumis melo L.); Perfil térmico

ORCID ID: Mallek-Ayadi S https://orcid.org/0000-0001-9731-6113, Bahloul N https://orcid.org/0000-0002-45851891, Kechaou N https://orcid.org/0000-0003-1375-228X

Citation/Cómo citar este artículo: Mallek-Ayadi S, Bahloul N, Kechaou N. 2019. Cucumis melo L. seeds as promising source of oil naturally rich in biologically active substances: Compositional characteristics, phenolic compounds and thermal properties. Grasas Aceites $\mathbf{7 0}$ (1), e284. https://doi.org/10.3989/gya.0215181

Copyright: (C2019 CSIC. This is an open-access article distributed under the terms of the Creative Commons Attribution 4.0 International (CC BY 4.0) License. 


\section{INTRODUCTION}

In the food industry, the manufacturing of vegetables and fruits generates the production of high amounts of agricultural materials such as peels, seeds and oilseed meals which are usually wasted and represent a serious environmental concern (da Silva and Jorge, 2014). These materials could be considered valuable by-products if the value of the subsequent products were to exceed the cost of further processing. In recent years, innovative features concerning the use of these by-products for further exploitation in the production of food additives or supplements with high nutritional value have gained interest since these are high-value products and their recovery may be economically attractive. Therefore, utilization of food processing by-products has increased the profitability of the food processing industry by reducing the cost of disposal of these by-products.

Seeds are regarded as the main by-products resulting from the processing of juices and wine, and they may be exploited as a source of oil and biologically active substances. There is Global trade interest in the retrieval and utilization of oils from natural plant sources (Carvalho et al., 2011). Indeed, seeds and seedoils obtained from fruit by-products are rich in bioactive compounds such as fatty acids, phytosterols and carotenoids (Górnaś et al., 2014).

Most kinds of Cucurbitaceae are promising sources of oil and their seeds have good nutrional value with important amounts of protein and oil (Nyam et al., 2009). This oil has been utilized for cooking and for pharmaceutical purposes (Azhari et al., 2014). Melon (Cucumis melo L.), which belongs to the Cucurbitaceae family, is a delicious fruit cultivated in warm regions of the world. The exceptional flavor of melon and its application in traditional medicine explain the economic importance of these fruits. The amount of melon seeds recovered during industrial fruit treatment was 738,000 tons based on the data of global fruit production and the percentage of seeds compared to the mass of the fruits (FAOSTAT, 2015). Despite the generation of enormous quantities, melon seeds are often discarded. Melon seeds have been reported to reduce cardiovascular desorders, help in regulating bloodfat levels (Yanty et al., 2008) and aid in controling type-2 diabetes (Chen and Kang, 2013). Melon seeds are also a good source of natural antioxidants. They have an important phenolic composition (Zeb, 2016) and they are considered as a valuable source of nutrients due to their protein, lipid, fiber and ash contents (Mallek-Ayadi et al., 2018). Furthermore, these seeds are used directly for human consumption as snacks after roasting and salting in Arabian countries (Nyam et al., 2009) and to add flavor to Indian dishes and desserts (Maran and Priya, 2015).

To our knowledge, scarce data has been reported on the physicochemical parameters and fatty acid composition of the oil extracted from melon (Cucumis melo L.) seeds. The fatty acids of melon seed oil of the Kalahari and tibish varieties were determined by Nyam et al., (2009) and Azhazi et al., (2014). These researchers confirmed that C18:2 (linoleic acid) was predominant in melon seed oil. The work of Yanty et al., (2008) aimed to investigate the physicochemical properties of Cucumis melo seeds inodorus variety. However, the literature is lacking scientific papers regarding polyphenols in melon seed oil. In a recent research, da Silva and Jorge (2014) studied the chemical composition of the oil obtained from the extraction of melon (Cucumis melo L.) seeds. The authors determined the total phenolic content of melon seed oil of the inodorus Naudin variety. Nevertheless, they did not identify the phenolic compounds present in this oil. Although some phenolic compounds of melon seed oil were quantified by HPLC, MallekAyadi et al., (2018) have found unknown compounds. This means that the phenolic composition of this oil may be more complex and much more variable. In addition, no previous reports are available on the sensory evaluation of melon seed oil.

An investigation of melon seed oil characteristics would be helpful to the industry to design machinery and quality control. Hence, the objectives of the present study were to determine the physicochemical parameters (acid value, peroxide value, saponification index, iodine value, refractive index, specific gravity, extinction coefficients $\left(\mathrm{K}_{232}\right.$ and $\left.\mathrm{K}_{270}\right)$ and color), triacylglycerols and fatty acids of the melon seed oil from the Maazoun variety. The bioactive substances, thermal analyses and sensorial properties were also studied in order to determine its nutritive value and potential applications.

\section{MATERIALS AND METHODS}

\subsection{Seed material}

Melons (Cucumis melo L. Maazoun cultivar) were harvested in Skhira, $80 \mathrm{Km}$ from the governorate of Sfax in Tunisia (geographic position $38^{\circ} 94^{\prime} \mathrm{N}$; $\left.9^{\circ} 21^{\prime} \mathrm{E}\right)$. The rinds were removed immediately and the seeds were carefully separated by hand from the pulp, cleaned and rinsed of any residual materials. The seeds were then dried in the oven at $40{ }^{\circ} \mathrm{C}$ for 24 hours. Dried seeds were finely milled in a grinding type moulinex to a fine powder. The particle-size of the powder has a maximum of $500 \mu \mathrm{m}$. The seed powder was stored and preserved in hermetic bags at $-20{ }^{\circ} \mathrm{C}$ until further analysis and oil extraction.

\subsection{Oil content}

The crude oil content of the sample was determined with a Soxhlet apparatus using hexane $(99 \%$ purity, Merck, Darmstadt, Germany) for extraction (method 920.39c, AOAC, 2000). 


\subsection{Oil extraction}

$50 \mathrm{~g}$ of melon seed powder were macerated for $4 \mathrm{~h}$ and then mixed with a solvent of $n$-hexane and placed in $1 \mathrm{~L}$ dark glass bottles at a ratio of seed powder weight to solvent volume of 1:5. The mixture was centrifuged for $15 \mathrm{~min}$ at $1000 \mathrm{~g}$. Then, the extract was filtered through Whattman filter paper. This procedure of maceration was done with two replications. The organic phase was eliminated in a rotary evaporator at $40^{\circ} \mathrm{C}$. A stream of gas was used to dry the seed oil, which was stored at $-20^{\circ} \mathrm{C}$ in amber flasks until analysis.

\subsection{Physicohemical analysis of oil}

The acid value (method $\mathrm{Cd} 3 \mathrm{~d}-63$ ), peroxide value (Cd 8-53), saponification index (Cd 3-25), iodine index (Cd 1-25), refractive index (Cc 7-25) and specific gravity (Cc 10 a-25) of the melon seed oil were determined according to AOCS Official methods (AOCS, 2012). The extinction coefficients from absorbances at 232 and $270 \mathrm{~nm}$ were obtained with a UV spectrophotometer using oil in cyclohexane $(1 \%)$ and a path length of one centimeter. Viscosity was calculated with a Rheologica Rheometer (Rheologica Instruments $\mathrm{AB}$, Lund, Sweden) at $25^{\circ} \mathrm{C}$ with a steel cone-plate (C40/4) at a constant shear rate of $100 /$ s.

\subsection{Carotenoid and chlorophyll determinations}

The pigments (chlorophylls and carotenoids) were performed by measuring the absorbance at 670 and $470 \mathrm{~nm}$, in cyclohexane using UV spectrophotometer (Shimadzu Co., Kyoto, Japan). The chlorophyll and carotenoid contents were calculated as follows (Chtourou et al., 2013):

$$
\begin{aligned}
& \text { Chlorphyll }(\mathrm{mg} / \mathrm{Kg})=\frac{(\mathrm{A} 670 \times 106)}{(613 \times 100 \times \mathrm{d})} \\
& \text { Carotenoid }(\mathrm{mg} / \mathrm{Kg})=\frac{(\mathrm{A} 470 \times 106)}{(2000 \times 100 \times \mathrm{d})}
\end{aligned}
$$

Where $\mathrm{A}$ is the absorbance of the oil at the respective wavelength and $\mathrm{d}$ is the spectrophotometer cell thickness $(1 \mathrm{~cm})$. The chlorophyll and carotenoid concentrations are expressed as $\mathrm{mg}$ per $\mathrm{kg}$ of oil, respectively.

\subsection{Color mesurements}

The CIELab coordinates of melon seed oil were generated directly by a spectrophotometer Konica Minolta colorimeter previously calibrated with a standard white calibration plate. In this coordinate system, $\mathrm{L}^{*}$ is an estimation of the relative luminosity of the seed oil; this parameter varies from 0 to
100 (black-white). A negative a* number designates green color; whereas an $a^{*}$ positive value indicates red-purple. The value of $b^{*}$ gives the yellowblue character with positive values for yellow shades and negative values for blues.

\subsection{Fatty acid composition}

The Regulation EEC/2568/91(EEC, 1991) was adopted to determine fatty acid methyl esters (FAMEs) which were prepared by the vigorous shaking of the seed oil solution in heptane with $0.2 \mathrm{~mL}$ of $2 \mathrm{~N}$ methanolic potassium hydroxide. Gas chromatography of FAMEs was performed on a Gas chromatograph (HP 6890 N, Agilent Technologies) fitted with a split/splitless injector at $230{ }^{\circ} \mathrm{C}$ and a flame ionization detector at $250{ }^{\circ} \mathrm{C}$. The column used was a capillary Agilent CP-Sil88 (length $50 \mathrm{~m}$; internal diameter $0.32 \mathrm{~mm}$; film thickness $0.20 \mu \mathrm{m}$ ). The temperature of the column was held at $180^{\circ} \mathrm{C}$; the carrier gas was helium at a flow rate of $1 \mathrm{~mL} / \mathrm{min}$; the split ratio was 1:50, with an injection volume of 1 $\mu \mathrm{L}$. FAME peak identification was determined by the comparison of retention times of the authentic samples in the same conditions. FAMEs were quantified according to their percentage area, obtained by integration of the peaks. The results were expressed as a percentage of individual fatty acids in the lipid fraction.

\subsection{Triacylglycerol composition}

The triacylglycerol profile was determined using a high-performance liquid chromatography (HPLC) apparatus, with an HP1100 Series instrument chromatograpic system (Agilent Technologies, Waldbronn, Germany) fitted with a differential refractometer detector (model RID10Avp; Shimadzu). A $0.25 \mathrm{~g}$ of oil sample was transferred to a graduated flask $(5 \mathrm{~mL})$ and dissolved with acetone $(9: 91, \mathrm{v} / \mathrm{v})$. After that, separation was made with an analytical spherisorb column $(250 \times 4.6 \mathrm{~mm})$ with a particle size of $5 \mu \mathrm{m}$ from Supelco (Bellefonte, PA, USA). The mobile phase was acetone/acetonitrile $(60: 40, \mathrm{v} / \mathrm{v})$ at a 1.50 $\mathrm{mL} / \mathrm{min}$ flow rate. All solvents were of high performance liquid chromatography grade. The column temperature was $30^{\circ} \mathrm{C}$; the injection volume was $20 \mu \mathrm{L}$ of sample solution prepared as indicated above. The total run time was one hour. The triacylglycerol peaks were identified based on the retention time of triacylglycerol standards: LLL, LLLn, OLL, OOL, POL, PLL, PLLn, PLP, OOO, POO, POP, PPO, POS, SOO, SLO and SLL (S, L, Ln, $\mathrm{O}$ and $\mathrm{P}$ are stearic, linoleic, linolenic, oleic and palmitic acids, respectively) purchased from Sigma (St Louis, MO, USA). Peak areas produced by the data integrator were used for quantification. 


\subsection{Extraction of phenolic compounds}

For the extraction of the phenolic fraction, an aliquot of $2 \mathrm{~mL}$ of $n$-hexane and $4 \mathrm{~mL}$ of a solution of $60: 40 \mathrm{methanol} /$ water were homogenized with $4 \mathrm{~g}$ of sample. After vigorous mixing, they were centrifuged at $1490 \mathrm{~g}$ for $3 \mathrm{~min}$. The extraction was performed twice and the hydroalcoholic phase was collected. Hydroalcoholic fractions were then united, washed with $4 \mathrm{~mL}$ of $n$-hexane to eliminate the residue of oil, concentrated and dried using a rotary evaporator at $35^{\circ} \mathrm{C}$.

\subsection{Determination of total phenolic content}

The total phenolic content was determined according to the the Folin Ciocalteu reagent method (Singleton and Rossi, 1965). An aliquot of $0.5 \mathrm{~mL}$ of the Folin reagent was added to $0.5 \mathrm{~mL}$ of extract. The mixture was stirred and incubated for $3 \mathrm{~min}$ in the dark. Then, $10 \mathrm{~mL}$ of a solution of $\mathrm{Na}_{2} \mathrm{CO}_{3}$ $(75 \mathrm{~g} / \mathrm{L})$ were added. The mixture was shaken and incubated for $1 \mathrm{~h}$ in the dark. Finally, the absorbance was measured at $750 \mathrm{~nm}$. The results were expressed as $\mathrm{mg}$ of gallic acid equivalents per $100 \mathrm{~g}$ extract (mg GAE/100 g extract). The value presented the average of three measurements.

\subsection{HPLC analysis of phenolic composition}

For the identification and quantification of melon seed oil phenolic compounds, thirty-four commercial standards were used. Standards were acquired from Sigma-Aldrich (St. Louis, MO, USA) and Extrasynthèse (Genay, France).

A stock solution of each phenolic compound standard was prepared at a concentration of $1 \mathrm{mg} /$ $\mathrm{mL}$ and stored in methanol. An intermediate solution containing all standard compounds was prepared in methanol for the calibration curve. A stock solution of cinnamic acid, used as an internal standard $(1 \mathrm{mg} / \mathrm{mL})$, was also prepared and stored in methanol. Standard stock solutions were filtered through a $0.45 \mu \mathrm{m}$ membrane and stored at $-20{ }^{\circ} \mathrm{C}$.

For the HPLC analysis, an aliquot of $100 \mu \mathrm{L}$ of cinnamic acid (1 $\mathrm{mg} / \mathrm{mL})$ (internal standard) was added to $100 \mu \mathrm{L}$ of melon seed oil extract. Samples were passed through a $0.45 \mu \mathrm{m}$ membrane filter before injection.

The qualitative evaluation of phenolic compounds was carried out using a high performance liquid chromatography technique, Hewlett-Packard system (Waldbronn, Germany) comprising a HP-1100 pump, a Rheodyne model 7725 injector (Cotati, CA), a UV detector $(280 \mathrm{~nm})$ and a C18 analytical column $(250 \mathrm{~mm} \times 8 \mathrm{~mm})$. The mobile phase consisted of acetonitrile (solvent A) and water with $0.2 \%$ sulphuric acid (solvent $\mathrm{B}$ ). The flow rate was kept at $0.5 \mathrm{~mL} / \mathrm{min}$. The gradient program was as follows: $15 \% \mathrm{~A} / 85 \% \mathrm{~B}, 0-12 \mathrm{~min} ; 40 \% \mathrm{~A} / 60 \% \mathrm{~B}$, 12-14 min; 60\% A/40\% B, 14-18 min; $80 \% \mathrm{~A} / 20 \% \mathrm{~B}$, $18-20 \mathrm{~min} ; 90 \% \mathrm{~A} / 10 \% \mathrm{~B}, 20-24 \mathrm{~min} ; 100 \%$ A, 24-28 min. The injection volume was $20 \mu \mathrm{L}$. The data were stored and processed by a HPLC Chemstation (Dos Series) (Hewlette Packard). Peaks were identified by comparison of their retention times with the corresponding standards. Analyses were performed in triplicate. The amounts of phenolic compounds were expressed as $\mathrm{mg}$ of phenols per $100 \mathrm{~g}$ of dry weight (DW).

\subsection{Oxidative stability by Rancimat}

The oxidative-stability was measured using a Rancimat apparatus (MetrohomSeries 743). The stage of stabilization was deliberated by the oxidative induction time using $3 \mathrm{~g}$ of sample. The temperature was set at $100{ }^{\circ} \mathrm{C}$ and the air flow rate was $20 \mathrm{~L} / \mathrm{h}$. For the duration of the oxidation procedure, the formation of volatile acids in a receiving flask filled with distilled water $(60 \mathrm{~mL})$ was measured by conductometry. The values obtained were defined as induction time.

\subsection{Thermal analysis by a differential scanning calorimeter (DSC)}

Thermal analysis of the oil was carried out using a differential scanning calorimeter (Thermal analysis DSC-204, Germany). Seed oil samples were weighed in a differential scanning calorimeter aluminium pan. An unfilled DSC-pan was used as an inert reference. The reference and sample pans were then positioned within the calorimeter and cooled to $-50{ }^{\circ} \mathrm{C}$ at $10{ }^{\circ} \mathrm{C} / \mathrm{min}$ and held for $10 \mathrm{~min}$. Then the temperature was increased to $100{ }^{\circ} \mathrm{C}$ at $10^{\circ} \mathrm{C} /$ min. This process was repeated and the DSC thermographs were traced in melting transition.

\subsection{Sensory evaluation}

The sensorial properties of melon seed oil were compared with those of sunflower and virgin olive oil. Oil samples were presented in a perfectly homogeneous and anonymous way (identical conditions of preparation and presentation) with a simple coding of three numbers. The oil samples were served to untrained panel consisting of sixty panelists of both sexes ( 30 males and 30 females) from the staff members and students of the National Engineering School of Sfax in Tunisia. Their ages ranged from 23 to 48 . The samples prepared for tasting were reserved in tasting glasses at $28^{\circ} \mathrm{C}$ with $15 \mathrm{~mL}$ of oil.

Detailed directions on how to evaluate the samples were presented verbally before the panelists entered the cubicle area and then also in written form on the score paper. The panelists were given napkins and enough water to rinse their mouths between 
each sample. Small containers into which samples may be spit were also provided. The prepared oils were evaluated based on a nine-point hedonic scale (1: dislike extremely, 5: neither like nor dislike, 9: like extremely). Each consumer was provided three samples tagged with arbitrary three-digit codes and asked to assess the oils for color, odor, taste, appearance and overall appreciation.

\subsection{Statistical analysis}

All experiments were performed in triplicate and the results were expressed as the mean values and standard deviation. One-way analysis of variance (ANOVA) was used to determine significant differences among means and Tukey's test was used to perform multiple comparisons among means using SPSS software (version 20.0; SPSS Inc., Chicago, IL, USA). The significance level was defined as $p<0.05$.

\section{RESULTS AND DISCUSSION}

\subsection{Yield oil of seeds}

The lipid fraction obtained from the extraction of melon seeds (Maazoun variety) presented a yield of $30.65 \%$, on dry weight. Such a yield may be considered economically important when compared to conventional oilseeds such as soy and corn, which contain $18-20 \%$ and $3.1-5.7 \%$ of oil, respectively (O'Brien, 2004). Belonging to the same botanical family (Cucurbiatceae), the oil content of Maazoun melon seed was higher than agrestis melon $(23.33 \%)$, bitter melon (19.30\%) and Kalahari melon (30.50\%) seeds (Mariod et al., 2009; Nyam et al., 2009). Our findings were in agreement with the inodorus Naudin melon seeds with $30.60 \%$ of oil (da Silva and Jorge, 2014). According to Nyam et al., (2009), variations in oil yield may be assigned to differences in plant variety, cultivation climate, ripening stage and the extraction method excerted. The notable percentage of oil makes Maazoun melon seeds convenient for application in the oil industry. For this reason, the profile characteristics and thermal properties of this oil should be investigated.

\subsection{Physicochemical characteristics of oil}

The quality parameters used frequently to evaluate the chemical and physical caracteristics of edible oils are contents in free fatty acids, peroxide value, saponification value, iodine value and refractive index. Table 1 summarizes the physical and chemical properties of melon seed oil (Maazoun variety). Free fatty acid (FFAs) content is an important quality parameter and it gives information about the shelf- life of oil, since FFA can change
TABLE 1. Physicochemical characteristics of Cucumis melo L. seed oil (Maazoun variety).

\begin{tabular}{lc}
\hline Parameter & Value \\
\hline Free fatty acids $(\%)$ & $0.31 \pm 0.06$ \\
Peroxide value (meq $\left.\mathrm{O}_{2} / \mathrm{kgoil}\right)$ & $0.50 \pm 0.20$ \\
Saponification value $(\mathrm{mg} \mathrm{KOH} /$ goil) & $179.80 \pm 0.11$ \\
Iodine value $\left(\mathrm{g} \mathrm{I}_{2} / 100 \mathrm{~g}\right.$ oil) & $139.50 \pm 0.53$ \\
Refractive index $\left(25^{\circ} \mathrm{C}\right)$ & $1.47 \pm 0.00$ \\
Specific gravity $\left(25^{\circ} \mathrm{C}\right)$ & $0.91 \pm 0.00$ \\
Extinction coefficient $\mathrm{K}_{232}$ & $1.21 \pm 0.13$ \\
Extinction coefficient $\mathrm{K}_{270}$ & $0.42 \pm 0.07$ \\
Viscosity (mPa.s) & $90.75 \pm 0.25$ \\
Carotenoid $(\mathrm{mg} / \mathrm{kg})$ & $2.43 \pm 0.03$ \\
Chlorophyll $(\mathrm{mg} / \mathrm{kg})$ & $5.70 \pm 0.08$ \\
Total phenolic compounds $(\mathrm{mg} / 100 \mathrm{~g})$ & $22.63 \pm 0.85$ \\
Color $\mathrm{L}^{*}$ & $48.42 \pm 0.84$ \\
$\mathrm{a}^{*}$ & $-5.81 \pm 0.18$ \\
$\mathrm{~b}^{*}$ & $15.29 \pm 0.73$ \\
\hline
\end{tabular}

All determinations were carried out in triplicate and mean value \pm standard deviation.

the physicochemical or organoleptic caracteristics of fat. FFA content in melon seed oil was found to be $0.31 \%$ (Table 1 ). This low value revealed that melon seed oil was edible oil with nutritive value. Moreover, this meant that Maazoun seed oil was nearly free from the hydrolytic rancidity brought about by enzymes.

The peroxide value measures the amount of hydro peroxide in the fat and allows for determining the auto-oxidation of oils. The peroxide value of melon seed oil was equal to 0.5 meq $\mathrm{O}_{2} / \mathrm{kg}$ of oil. This value was lower than that reported by Azhari et al., (2014) for melon seed oil (2.5 meq $\mathrm{O}_{2} / \mathrm{kg}$ oil) from Sudan. The saponification index indicates the presence or absence of triacylglycerols with high molecular weight in vegetable oils. The saponification index of Maazoun melon seed oil $(179.8 \mathrm{mg} / \mathrm{g}$ oil) was higher than that described in the literature by Nyam et al., (2009) for Kalahari melon seed oil (173.2 mg KOH/g oil) although lower than that of bitter melon seed oil (190.7 mg KOH/g oil), as observed by the same authors.

Iodine value is used to measure the average number of double bonds or unsaturation in fats. The iodine value of melon seed oil was determined as $139.5 \mathrm{~g} \mathrm{I}_{2} / 100 \mathrm{~g}$ oil. Compared to melon seed oils from other geographical origins, this value was higher than the iodine values for melon seed oil from Malaysia (125 $\mathrm{g} \mathrm{I}_{2} / 100 \mathrm{~g}$ oil) and Sudan (110.99 $\mathrm{g} \mathrm{I}_{2} / 100 \mathrm{~g}$ oil) (Nyam et al., 2009; Azhari et al., 2014). Such a high value might indicate that melon seed oil from Tunisia possesses higher contents in unsaturated fatty acids than most melon seed oils. Thus, it possessed adequate qualities of drying oil purposes 
and edible oil. The iodine value was situated within the interval of values for other edible vegetable oils and varied from 95 to $145 \mathrm{~g} \mathrm{I}_{2} / 100 \mathrm{~g}$ (Tan and Che Man, 2002).

The refraction index increases with the unsaturation level of the oil. The refractive index of melon seed oil (1.47) was found to be higher than the previously reported value (1.44) by Azhari et al., (2014). The obtained value for specific gravity $(0.91)$ was in agreement with the value found for melon seed oil of the tibish variety (Azhari et al., 2014). The oxidative state of every plant oil may be assessed from the specific absorption at $232 \mathrm{~nm}\left(K_{232}\right)$ and $270 \mathrm{~nm}$ $\left(K_{270}\right)$ which designates, respectively, the presence of primary and secondary oxidation products. The extinction coefficients $\left(K_{232}\right.$ and $\left.K_{270}\right)$ were found to be 1.21 and 0.42 , respectively. These results suggested that Maazoun melon seed oil's stability to oxidation was relatively good.

The viscosity of melon seed oil (90.75 mPa.s) was lower than that reported by Gohari Ardabili et al., (2011) for pumpkin seed oil (93.66 mPa.s), yet, it was higher than those of most vegetable oils such as sunflower (59.7 mPa.s), soybean (63.23 mPa.s) and groundnut (69.04 mPa.s) oils due to the presence of long chain fatty acids such as linoleic and oleic acids (Chouaibi et al., 2012). Similarly, Hellier et al., (2015) reported an obvious trend in the relationship between fatty acids' chain length and viscosity. The authors confirmed the influence of fatty acid double bonds on viscosity.

\subsection{Carotenoid and chlorophyll}

The chlorophyll and carotenoid contents of melon seed oil of the Maazoun variety are illustrated in Table 1. Melon seed oil accounted for $2.43 \mathrm{mg} /$ $\mathrm{kg}$ of carotenoids which explained the yellow color of seed oil from Maazoun variety. This amount was lower than that of virgin olive oil with $3.70 \mathrm{mg} / \mathrm{kg}$ (Issaoui et al., 2010). With regards to chlorophyll, melon seed oil was found to contain $5.70 \mathrm{mg} / \mathrm{kg}$. This value was higher than that of fig achenes oil $(1.05 \mathrm{mg} / \mathrm{kg})$ (Soltana et al., 2016). However, it was lower than that of virgin olive oil $(9.32-12.67 \mathrm{mg} / \mathrm{kg})$ (Aparicio et al., 1999). These pigments are beneficial because they simulate the appearance of annattos and carotenes frequently used in the fat industry (Oomah et al., 2000). From a nutritional point of view, carotenoids are sources of vitamin A and they play an important role in the oxidative stability of vegetable oils.

\subsection{Color}

The CIE-Lab values ( $\mathrm{L}^{*}, \mathrm{a}^{*}, \mathrm{~b}^{*}$ ) of melon seed oil were $48.42,-5.81$ and 15.29 , respectively. For comparison purposes, Cucumis melo seed oil of the Maazoun variety showed a higher $L^{*}$ value and lower $\mathrm{a}^{*}$ and $\mathrm{b} *$ values than pumpkin (Cucurbita maxima) seed oil (Rezig et al., 2012). This indicates that melon seed oil was lighter in color. The CIE-Lab coordinates ( $\left.\mathrm{L}^{*}, \mathrm{a}^{*}, \mathrm{~b}^{*}\right)$ values for other vegetable oils, such as olive, sunflower, palm, corn and soybean ranged from 63.4 to $69.50,3.80$ to 4.40 and 9.20 to 10.40 , respectively (Hsu and $\mathrm{Yu}, 2002$ ). Hence, melon seed oil was differentiated by a negative value of the a* coordinate which was clearly lower than that of other vegetable oils. Moreover, the melon seed oil's $b^{*}$ value was higher than those of common vegetable oils. Thereby, Cucumis melo seed oil was more golden than the vegetable oils examined by $\mathrm{Hsu}$ and $\mathrm{Hu}$ (2002). This means the attendance of yellow pigments like carotenoids.

\subsection{Total phenolic content}

The phenolic compounds have a significant importance due to their nutritional and technological properties. As shown in table 1, the total phenolic content of melon seed oil was $22.63 \mathrm{mg} / 100 \mathrm{~g}$ oil, which was higher than that of melon inodorus of the Naudin variety (13.07 mg/100g oil) (da Silva and Jorge, 2014). However, melon seed oil of the Maazoun variety had a relatively lower phenol content compared to olive oil, which is considered as a rich source of phenolic compounds in the Mediterranean diet. In fact, Ouni et al., (2011) reported that the total phenolic content of olive oil of the Oueslati cultivar ranged from 33.48 to $85.98 \mathrm{mg} / 100 \mathrm{~g}$ oil.

Phenolic compounds have a positive effect in the prevention of cancer and coronary heart disease. Furthermore, the high amount of polyunsaturated fatty acids could make melon seed oil prone to oxidation. However, this could be avoided by the natural phenolic compounds that protect the melon seed oil. Phenolics exert a beneficial effect on the oxidative stability of vegetable oils. According to Aparicio et al., (1999), the contribution of polyphenols in the oxidative stability of olive oil was about $51 \%$, fatty acids, $24 \%$ and in lower percentages in carotenoids and chlorophylls.

\subsection{Fatty acids}

The fatty acid composition is an essential indicator of the nutritional value of oils. The data about the fatty acid profile of melon seed oil from the Maazoun variety is presented in Table 2 . This composition was dominated by $\mathrm{C} 18: 2$ (68.98\%), C18:1 (15.84\%), C16:0 $(8.76 \%)$ and $\mathrm{C} 18: 0$ (5.64\%). Melon seed oil belongs to the linoleic-oleic group of oil. These results are in agreement with previously published studies on other varieties such as Honeydew and inodorus Naudin, in which the main fatty acids were linoleic $(59-59.04 \%)$, oleic $(24.71-26.4 \%)$, palmitic $(8.7-9.57 \%)$ and stearic acid (5.3-5.74\%) (da Silva and Jorge, 2014; Górnaś and Rudzińska, 2016). According to Oomah et al., 
TABLE 2. Fatty acid composition of Cucumis melo L. seed oil (Maazoun variety)

\begin{tabular}{lc}
\hline Fatty acid & Composition (\%) \\
\hline ESFA & 14.76 \\
Myristic acid (C14:0) & $0.04 \pm 0.01$ \\
Pentadecanoic acid (C15:0) & $0.03 \pm 0.01$ \\
Palmitic acid (C16:0) & $8.76 \pm 0.07$ \\
Margaric acid (C17:0) & $0.07 \pm 0.00$ \\
Stearic acid (C18:0) & $5.64 \pm 0.06$ \\
Arachidic acid (C20:0) & $0.16 \pm 0.01$ \\
Lignoceric acid (C24:0) & $0.06 \pm 0.01$ \\
EUFA & 85.41 \\
Palmitoleic acid (C16:1) & $0.08 \pm 0.02$ \\
Margaroleic acid (C17:1) & $0.03 \pm 0.01$ \\
Oleic acid (C18:1) & $15.84 \pm 0.03$ \\
Linoleic acid (C18:2) & $68.98 \pm 0.05$ \\
Linolenic acid (C18:3) & $0.20 \pm 0.00$ \\
Gondoic acid (C20:1) & $0.26 \pm 0.01$ \\
Erucic acid (C22:1) & $0.02 \pm 0.01$ \\
EMUFA & 16.23 \\
EPUFA & 69.18 \\
UFA/SFA & 5.79 \\
\hline Al
\end{tabular}

All determinations were carried out in triplicate and mean value \pm standard deviation.

SFA: saturated fatty acids; UFA: unsaturated fatty acids; MUFA: monounsaturated fatty acids; PUFA: polyunsaturated fatty acids.

(2000), linoleic acid has favorable nutritional implications and beneficial physiological effects in the prevention of cancer. Hence, melon seed oil has important nutritional value due to the adequate levels of linoleic and oleic acids which constituted more than $84 \%$ of total fatty acids. Additionally, melon seed oil contains arachidic, linolenic and gondoic acids, but in much smaller amounts $(0.16-0.25 \%)$. Trace amounts $(<0.1 \%)$ of myristic, pentadecanoic, margaric, lignoceric, palmitoleic, heptadecenoic and erucic acids were also detected.

In the current study, the percentage of the different types of fatty acids in melon seed oil recovered from the Maazoun cultivar were as follows: saturated (14.76\%), monounsaturated (16.23) and polyunsaturated $(69.18 \%)$. A similar observation was made by Azhari et al., (2014) in tibish melon seed oil (saturated 19.81\%; monounsaturated $18.92 \%$; polyunsaturated $61.26 \%$ ). The potential reason for the differences in the composition of fatty acids of melon seed oils could be accredited to varietal differences and abiotic factors such as climate conditions, horticultural measures and water availability.

The Maazoun melon seed oil showed an unsaturated/saturated fatty acid ratio of 5.79 (Table 2). A similar ratio of fatty acid content was found in the
TABLE 3. Triacylglycerol composition of Cucumis melo L. seed oil (Maazoun variety).

\begin{tabular}{lcc}
\hline Triacylglycerol & ECN & Relative composition (\%) \\
\hline LLL & 42 & $28.99 \pm 0.01$ \\
OLL & 44 & $23.94 \pm 0.01$ \\
PLL & 44 & $20.75 \pm 0.02$ \\
OOL & 46 & $4.87 \pm 0.08$ \\
POL & 46 & $16.13 \pm 0.02$ \\
PLP & 46 & $0.60 \pm 0.005$ \\
SLL & 46 & $0.69 \pm 0.02$ \\
OOO & 48 & $3.60 \pm 0.01$ \\
POP & 48 & $0.25 \pm 0.00$ \\
SLO & 48 & $0.17 \pm 0.01$ \\
\hline
\end{tabular}

Values are mean of three replicate samples $(n=3)$, mean \pm standard deviation.

$\mathrm{L}$, linoleic; $\mathrm{O}$, oleic; $\mathrm{P}$, palmitic; $\mathrm{S}$, stearic; $\mathrm{ECN}$, equivalent carbon number.

melon seed oil from the Honeydew variety (UFA/ SFA = 5.9) (da Silva and Jorge, 2014). It is wellknown that the digestibility and quality of edible vegetable oils are determined by the quantity and composition in unsaturated fatty acids. According to El-Adawy and Taha (2001), the presence of unsaturated fatty acids in sufficient amounts raises great interest. Polyunsaturated fatty acids lower cardiovascular risk and their consumption should be encouraged. Consequently, melon seed oil may be recommended as a dietetic oil and suggested as a dietary supplement for diverse food purposes.

\subsection{Triacylglycerols composition}

The determination of the triacylglycerol profile has been considered an evaluation of the quality and purity of plant oils. The analysis of triacylglycerol molecular species in Maazoun melon seed oil revealed that trilinolein (LLL), oleo dilinolein (OLL) and palmitoyl dilinolein (PLL) were the most abundant triacylglycerols (Table 3). Therefore, linoleic acid was a major component in the three main types of triacylglycerols (LLL, OLL, and PLL). This can be explained by the fatty acid composition in which linoleic acid presents the highest concentration (68.98\%; Table 2). It was remarkable that a close correspondence existed between the fatty acid composition and triacylglycerol profile of the oil. Maazoun melon seed oil also contained POL (Palmitoyl Oleoyl Linoleoylglycerol) in a lower quantity $(16.13 \%)$. In comparison, these results were similar to the previous study by Yanty et al., (2008) for Honeydew melon seed oil which had the following amounts of major triacylglycerols: LLL $(24.90 \%)$, OLL $(21.50 \%)$, PLL $(15.90 \%)$ and POL $(12.40 \%)$. Likewise, watermelon seed oil showed a triacylglycerol composition with dominance of 
LLL (29.5\%) and OLL (21.7\%) (Conto et al., 2011). However, da Silva and Jorge (2014) reported that OLL $(33.10 \%)$ was the main triacylglycerol followed by LLL $(24.70 \%)$ for melon seed oil from the variety inodorus Naudin. The differences in triacylglycerol amounts and types were accredited to the oil source and product processing and were mainly governed by percentages of the individual fatty acids. Furthermore, Maazoun melon seed oil contained relatively small quantities of OOL $(4.87 \%)$ and OOO (3.60\%).

In Table 3, all the triacylglycerols were grouped according to their equivalent carbon number (ECN). Melon seed oil contained four triacylglycerol species (from ECN42 to ECN48) in which triacylglycerols with ECN44 were dominant (44.69\%), followed by TAGs ECN42 (28.99\%), TAGs ECN46 (22.29\%) and TAGs ECN48 (4.02\%).

\subsection{Identification of phenolic compounds}

The quantitative analysis showed that melon seed oil from the Maazoun variety contains fourteen phenolic compounds (Table 4). Among these compounds, several flavonoids and phenolic acids were identified. The HPLC characterization of melon seed oil revealed that the amentoflavone, luteolin-7-O-glycoside and gallic acid were the major phenolic compounds accounting for 3.88 $\mathrm{mg} / 100 \mathrm{~g}, 1.26 \mathrm{mg} / 100 \mathrm{~g}$ and $0.93 \mathrm{mg} / 100 \mathrm{~g}$, respectively. Defined as plant flavonoids, the presence of amentoflavone has been associated with an antidiabetic function; whereas the luteolin-7-Oglycoside possesses antioxidant and antibacterial

TABle 4. Phenolic compounds (mg/100g) in Cucumis melo L. seed oil from the Maazoun variety.

\begin{tabular}{lc}
\hline Phenolic compounds & Composition \\
\hline Protocatechuic acid & $0.30 \pm 0.00$ \\
Caffeic acid & $0.41 \pm 0.01$ \\
Gallic acid & $0.93 \pm 0.03$ \\
Vanillic acid & $0.61 \pm 0.01$ \\
Luteolin -7-O-glycoside & $1.26 \pm 0.02$ \\
Naringenin & $0.67 \pm 0.02$ \\
Syringic acid & $0.44 \pm 0.00$ \\
p-coumaric acid & $0.60 \pm 0.01$ \\
Oleuropein & $0.17 \pm 0.05$ \\
Rosmarinic acid & $0.28 \pm 0.02$ \\
Pinoresinol & $0.40 \pm 0.01$ \\
Apigenin & $0.39 \pm 0.01$ \\
Flavone & $0.49 \pm 0.02$ \\
Amentoflavone & $3.88 \pm 0.11$ \\
\hline
\end{tabular}

All determinations were carried out in triplicate and mean value \pm standard deviation. properties. Gallic acid seems to have antifungal and antiviral properties. It acts as an antioxidant and helps to protect cells against oxidative damage (Soong and Barlow, 2006). Melon seed oil was also found to contain naringenin, vanillic acid, $p$-coumaric acid, flavones and syringic acid, although in smaller amounts ranging from $0.44 \mathrm{mg} / 100 \mathrm{~g}$ to $0.67 \mathrm{mg} / 100 \mathrm{~g}$ (Table 4). However, compared to the same variety, vanillic, $p$-coumaric and syringic acids were not detected in the melon seed oil of the Maazoun variety (Mallek-Ayadi et al.,2018). Interestingly, vanillic acid as well as $p$-coumaric acid are components with important anticancer activity (Rocha et al., 2012); whereas syringic acid possesses antibacterial ability against several microorganisms (Shi et al., 2016). In comparision with other melon varieties, some of the phenolic compounds identified in this study had not been previously reported for Kalahari melon seed oil (Nyam et al., 2009), in particular rosmarinic acid, which exihits important biological activities including antioxidant properties.

The health benefits associated with the intake of polyphenols of plant origin have been scientifically established. Thereby, melon seeds are potentially a source of natural antioxidants which can be used for the prevention of oxidative stress in the human body. It is worth noting that during storage, phenolic compounds protect the polyunsaturated fatty acids of vegetable oils against oxidation by exerting their antioxidant role. Additionally, edible oils rich in natural antioxidants may play a role in reducing the risk of chronic diseases. Thus, the examined oil could be utilized in diverse food preparations to provide nutrition and health benefits.

\subsection{Oxidative stability}

Oxidative stability is the determination of oxidation induction time of oil and hence its resistance to oxidative phenomena. The oxidative stability index is a significant parameter to evaluate the quality of edible oils. The stability of melon seed oil, evaluated by the Rancimat method, was about 7.20 hours at $100{ }^{\circ} \mathrm{C}$. At the same temperature, the Rancimat induction time of pumpkin seed oil was $18.61 \mathrm{~h}$ (Rezig et al., 2012). The melon seed oil was thus less resistant to oxidation than pumpkin seed oil. With regard to the literature, it is observed that tibish seed oil presented lower stability $(4.28 \mathrm{~h})$ against oxidation (Azhari et al., 2014). It seems that an arrangement of some composites is probably responsible for the good oxidative stability of unsaturated fatty acids. Decker (1998) reported that the oxidative stability could be improved by controlling the composition and the activity of reaction substrates and minimizing thus the use of food additives. 


\subsection{Thermal analysis}

Differential scanning calorimetry (DSC) is an efficient method to evaluate the physical and thermal caracteristics of oils. The DSC heating parameters assist in discovering the character of the phase evolution which take place when the oils are melted. As shown in figure 1, melon seed oil (Maazoun variety) presented a simple thermogram with two different peaks: a primary temperature melting peak possessing a peak temperature of $-46.02{ }^{\circ} \mathrm{C}$, a melting enthalpy $88.41 \mathrm{~J} / \mathrm{g}$ and an onset temperature $-50.76{ }^{\circ} \mathrm{C}$ followed by a melting peak with a temperature of $-19.5^{\circ} \mathrm{C}$, a melting enthalpy of $138.15 \mathrm{~J} / \mathrm{g}$ and an onset temperature of $-25.81^{\circ} \mathrm{C}$. The melting of the polymorphic forms of triacylglycerols which possess weaker stability could explain the record of the initial endothermic transition observed in the heating thermogram of melon seed oil. The second endothermic peak was clearly discernible in the melon seed oil and may be due to the moresteady polymorphic form or to the presence of highermelting triacylglycerols. The same trend was found by Cheikh-Rouhou et al., (2007) for the Tunisian variety of Nigella sativa seed oil. The thermal properties of fats were found to correspond with their

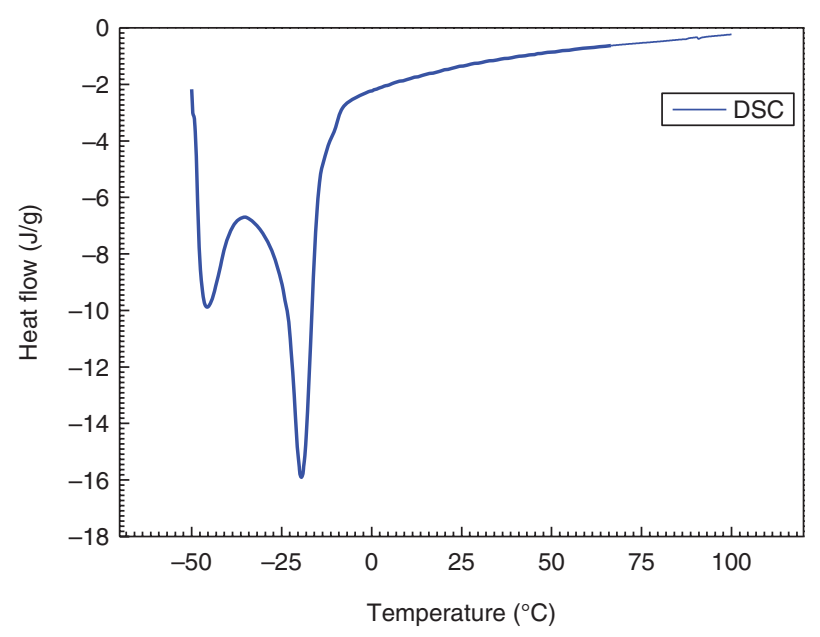

Figure 1. Melting thermogram of Cucumis melo L. (Maazoun variety) seed oil. constitution especially the chain length of fatty acids, level of unsaturation and the distribution of fatty acids in triacylglycerols (Bahloul et al., 2014).

\subsection{Sensory analysis}

The means of different sensory attributes (color, odor, taste, appearance and overall appreciation) of sunflower oil, melon seed oil and virgin olive oil are presented in table 5 . The results of the hedonic analysis show that virgin olive oil is more appreciated by tasters than the other two vegetable oils (melon seed oil and sunflower oil) since it obtained the highest scores for all organoleptic attributes evaluated. In addition, the results from the sensory evaluation indicated that melon seed oil is also appreciated by tasters. In fact, there is no significant difference ( $p$-value $>0.05)$ in color, taste and appearance between virgin olive oil and melon seed oil. Therefore, this unconventional oil extracted from melon seed of the Maazoun cultivar can be used like other vegetable food oils in culinary preparations and food formulations.

\section{CONCLUSIONS}

The present work shows that the melon seeds of the Maazoun variety provide an appreciable oil yield. The physicochemical characteristics asserted the added-value of the extracted oil as a dietary supplement for food applications. Moreover, melon seed oil seems to be a new promising source of biologically active substances and could be used as a functional ingredient. In fact, phenolic compounds and carotenoids are of nutritional importance for use in industrial applications. Therefore, the appropriate utilization of melon seeds may constitute an example for the valorization of fruit by-products to produce a promising new source of oil which is not widespred in the food industry yet it is not inferior in quality from the common vegetable oils.

\section{ACKNOWLEDGMENTS}

This work was supported by the Ministry of Higher Education and Scientific Research of Tunisia.

TABLE 5. Sensory evaluation of melon (Cucumis melo L.) seed oil of the Maazoun variety.

\begin{tabular}{lccccc}
\hline Oil & Color & Odor & Taste & Appearance & Overall appreciation \\
\hline Sunflower oil & $1.86 \pm 0.71^{\mathrm{a}}$ & $2.00 \pm 0.38^{\mathrm{a}}$ & $1.83 \pm 0.74^{\mathrm{a}}$ & $1.86 \pm 0.62^{\mathrm{a}}$ & $1.76 \pm 0.32^{\mathrm{a}}$ \\
Melon seed oil & $3.01 \pm 0.59^{\mathrm{b}}$ & $2.53 \pm 0.97^{\mathrm{a}}$ & $2.40 \pm 0.25^{\mathrm{a}, \mathrm{b}}$ & $2.63 \pm 0.76^{\mathrm{b}}$ & $2.86 \pm 0.53^{\mathrm{b}}$ \\
Virgin olive oil $^{\mathrm{b}}$ & $3.03 \pm 0.29^{\mathrm{b}}$ & $3.50 \pm 0.51^{\mathrm{b}}$ & $3.06 \pm 0.34^{\mathrm{b}}$ & $2.86 \pm 0.33^{\mathrm{b}}$ & $3.23 \pm 0.41^{\mathrm{c}}$ \\
\hline
\end{tabular}

All values given are means of three determinations, mean \pm standard deviation.

No significant difference $(p>0.05)$ among mean values in the same column and followed by the same letters (Tukey's test), significance at $(p<0.05)$. 


\section{REFERENCES}

A.O.A.C. 2000. Association of Official Analytical Chemists: Official Methods of Analysis. 17th Edition. Gaithersburg, MD, USA.

A.O.C.S. 2012. American Oil Chemists' Society. Official Methods and Recommended Practices of the American Oil Chemists' Society. 6th Edition. Champaign, IL, USA.

Aparicio R, Roda L, Albi MA, Gutierrez F. 1999. Effect of various compounds on virgin olive oil stability measured by Rancimat. J. Agric. Food Chem. 47, 4150-4155. https://doi. org/10.1021/jf9812230

Azhari S, Xu YS, Jiang QX, Xia WS. 2014. Physicochemical properties and chemical composition of Seinat (Cucumis melo var. tibish) seed oil and its antioxidant activity. Grasas Aceites 65, 1-8. https://doi.org/10.3989/gya.074913

Bahloul N, Kechaou N, Mihoubi NB. 2014. Comparative investigation of minerals, chlorophylls contents, fatty acid composition and thermal profiles of olive leaves (Olea europeae L.) as by-product. Grasas Aceites 65, 3-35. https://doi. org/10.3989/gya.0102141

Carvalho IS, Teixeira MC, Brodelius M. 2011. Fatty acids profile of selected Artemisia spp. plants: Health promotion. $L W T$ -Food Sci. Technol. 44, 293-298. https://doi.org/10.1016/j. lwt.2010.05.033

Cheikh-Rouhou S, Besbes S, Hentati B, Blecker C, Deroanne C, Attia H. 2007. Nigella sativa L.: Chemical composition and physicochemical characteristics of lipid fraction. Food Chem. 101, 673-681. https://doi.org/10.1016/j. foodchem.2006.02.022

Chen L, Kang YH. 2013. In vitro inhibitory effect of oriental melon (Cucumis melo L. var. makuwa Makino) seed on key enzyme linked to type 2 diabetes. J. Func. Foods 5, 981-986. https://doi.org/10.1016/j.jff.2013.01.008

Chouaibi M, Mahfoudhi N, Rezig L, Donsì F, Ferrari G, Hamdi S. 2012. Nutritional composition of Zizyphus lotus L. seeds. J. Sci. Food Agric. 92, 1171-1177. https://doi. org/10.1002/jsfa.4659

Chtourou M, Gargouri B, Jaber H, Abdelhedi R, Bouaziz M. 2013. Comparative study of olive oil quality from Chemlali Sfax versus Arbequina cultivated in Tunisia. Eur. J. Lipid Sci. Technol. 115, 631-640. https://doi.org/10.1002/ ejlt.201200234

Conto LC, Gragnani MAL, Maus D, Ambiel HCI, Chiu MC, Grimaldi R. 2011. Characterization of crude watermelon seed oil by two different extractions methods. J. Am. Oil Chem. Soc. 88, 1709-1714. https://doi.org/10.1007/s11746-011-1850-8

Decker EA. 1998. Strategies for manipulating the prooxidative/antioxidative balance of foods to maximize oxidative stability. Trends Food Sc. Technol. 9, 241-248. https://doi. org/10.1016/S0924-2244(98)00045-4

EEC. 1991. Characteristics of olive and olive pomace oils and their analytical methods. Regulation EEC/2568/1991. Off. J. Eur. Com. L248, 1-82.

FAOSTAT. 2015. FAO Statistical Database. http://www.fao.org

Gohari Ardabili A, Farhoosh R, Haddad Khodaparast MH. 2011. Chemical Composition and Physicochemical Properties of Pumpkin Seeds (Cucurbita pepo Subsp. pepo Var. Styriaka) Grown in Iran. J. Agric. Sci. Technol. 13, 1053-1063.

Górnaś P, Rudzińska M. 2016. Seeds recovered from industry by-products of nine fruit species with a high potential utility as a source of unconventional oil for biodiesel and cosmetic and pharmaceutical sectors. Ind. Crops Prod. 83, 329-338. https://doi.org/10.1016/j.indcrop.2016.01.021

Górnaś P, Siger A, Juhneviča K, Lācis G, Snē E, Seglina D. 2014. Cold pressed Japanese quince (Chaenomeles japonica (Thunb) Lindl. ex Spach) seed oil as a rich source of a-tocopherol, carotenoids and phenolics: A comparison of the composition and antioxidant activity with nine other plant oils. Eur. J. Lipid Sci. Technol. 116, 563-570. https:// doi.org/10.1002/ejlt.201300425

Hellier P, Ladommatos N, Yusaf T. 2015. The influence of straight vegetable oil fatty acid composition on compression ignition combustion and emissions. Fuel 143, 131-14. https://doi.org/10.1016/j.fuel.2014.11.021
Hsu SY, Yu SH. 2002. Comparisons on 11 plant oil fat substitutes for low-fat kung-wans. J. Food Eng. 51, 215-220. https://doi.org/10.1016/S0260-8774(01)00059-0

Issaoui M, Flamini G, Brahmi F, Dabbou S, Ben Hassine K, Taamali A, Chehab H, Ellouz M, Zarrouk M, Hammami M. 2010. Effect of the growing area conditions on differentiation between Chemlali and Chetoui olive oils. Food Chem. 119, 220-225. https://doi.org/10.1016/j.foodchem.2009.06.012

Mallek-Ayadi S, Bahloul N, Kechaou N. 2018. Chemical composition and bioactive compounds of Cucumis melo L. seeds: Potential source for newtrends of plant oils. Process Saf. Environ. Prot. 113, 68-77. https://doi.org/10.1016/j. psep.2017.09.016

Maran JP, Priya B. 2015. Supercritical fluid extraction of oil from muskmelon (Cucumis melo) seeds. J. Taiwan Inst. Chem. Eng. 47, 71-78. https://doi.org/10.1016/j.jtice.2014.10.007

Mariod AA, Ahmed YM, Matthaus B, Khaleel G, Siddig A, Gabra AM, Abdelwahab SI. 2009. A Comparative Study of the Properties of Six Sudanese Cucurbit Seed and Seed Oils. J. Am. Oil Chem. Soc. 86, 1181-1188. https://doi. org/10.1007/s11746-009-1459-3

Nyam KL, Tan CP, Lai OM, Long K, Mana CYB. 2009. Physicochemical properties and bioactive compounds of selected seed oils. Food Sci. Biotechnol. 42, 1396-1403. https://doi.org/10.1016/j.lwt.2009.03.006

O'Brien RD. 2004. Fats and oils: Formulating and processing for applications. Bocca Raton, USA: CRC Press.

Oomah DB, Ladet S, Godfrey DV, Liang J, Girard B. 2000. Characteristics of rasberry (Rubus idaeus L.) seed oil. Food Chem. 69, 187-193. https://doi.org/10.1016/ S0308-8146(99)00260-5

Ouni Y, Flamini G, Issaoui M, Ben Youssef N, Cioni PL, Hammami M, Daoud D, Zarrouk M. 2011. Volatile compounds and compositional quality of virgin olive oil from Oueslati variety: Influence of geographical origin. Food Chem. 124, 1770-1776. https://doi.org/10.1016/j. foodchem.2010.08.023

Rezig L, Chouaibi M, Msaada K, Hamdi S. 2012. Chemical composition and profile characterization of pumpkin Cucurbita maxima seed oil. Ind. Crops Prod. 37, 82-87. https://doi.org/10.1016/j.indcrop.2011.12.004

Rocha LD, Monteiro MC, Anderson JT. 2012. Anticancer properties of hydroxycinnamic acids-A Review. Cancer Clin. Oncol. 1, 1927-4866. https://doi.org/10.5539/cco.v1n2p109

Shi C, Sun Y, Zheng Z, Zhang X, Song K, Jia Z, Chen Y, Yang M, Liu X, Dong R, Xia X. 2016. Antimicrobial activity of syringic acid against Cronobacter sakazakii and its effect on cell membrane. Food Chem. 197, 100-106. https://doi. org/10.1016/j.foodchem.2015.10.100

Silva AC da, Jorge N. 2014. Bioactive compounds of the lipid fractions of agro-industrial waste. Food Res. Int. 63, 493500. https://doi.org/10.1016/j.foodres.2014.10.025

Singleton VL, Rossi JA. 1965. Colorimetry of total phenolics with phosphomolybdic-phosphotungstic acid reagents. Am. J. Enol. Vitic. 16, 144-158.

Soltana H, Tekaya M, Amri Z, El-Gharbi S, Nakbi A, Harzallah A, Mechri B, Hammami M. 2016. Characterization of fig achenes' oil of Ficus carica grown in Tunisia. Food Chem. 196, 1125-1130. https://doi.org/10.1016/j.foodchem.2015.10.053

Soong YY, Barlow PJ. 2006. Quantification of gallic acid and ellagic acid from longan (Dimocarpus longan Lour.) seed and mango (Mangifera indica L.) kernel and their effects on antioxidant activity. Food Chem. 97, 524-530. https:// doi.org/10.1016/j.foodchem.2005.05.033

Tan CP, Che Man YB. 2000. Differential scanning calorimetric analysis of edible oils: Comparison of thermal properties and chemical composition. J. Am. Oil Chem. Soc. 77, 143-155. https://doi.org/10.1007/s11746-000-0024-6

Yanty NAM, Lai OM, Osman A, Long K, Ghazali HM. 2008. Physicochemical properties of Cucumis melo var. inodorus (honeydew melon) seed and seed oil. J. Food Lipids 15, 42-55. https://doi.org/10.1111/j.1745-4522.2007.00101.x

Zeb A. 2016. Phenolic Profile and Antioxidant Activity of Melon (Cucumis melo L.) Seeds from Pakistan. Foods 5, 67-74. https://doi.org/10.3390/foods5040067 